\title{
TASAWUF WUJŪDIYYAT: \\ Tinjauan Ulang Polemik Penyesatan Hamzah Fansūrī oleh Shaykh Nūr al-Dīn al-Ranīrī
}

\author{
Kiki Muhamad Hakiki \\ Universitas Islam Negeri Raden Intan, Lampung \\ e-mail: hakiki1981@gmail.com
}

\begin{abstract}
This paper aims to revisit the polemic between Hamzah Fansūrī and Shaykh and Nür al-Dīn al-Ranīin about the apostasy of Wujūdiyyat Mysticism of Hamzah Fansūrī expressed by Nür al-Dīn al-Ranīrī This polemic of Wujūdiyyat and Wahdat al-Wujüd in other term was not only interesting in its time. It is also relevant until now. Recent studies with a variety of disciplines have been working dozens of pieces on this problem. Based on research by using a set of research methods, it is found that the allegations filed by Shaykh Nür al-Dīn al-Ranìri against Hamzah Fansūrī are not proven. This shows that categorizing Hamzah Fansuri and his understanding as apostates is a misleading accusation.
\end{abstract}

\begin{abstract}
Abstrak: Tulisan ini bertujuan untuk meninjau kembali polemik antara Hamzah Fansūrī Syekh dan Nūr al-Din al-Ranīī tentang kesesatan tasawuf Wujūdiyyat Hamzah Fansūrī yang diungkapkan oleh Nūr al-Din al-Ranīrī. Polemik tentang Wujūdiyyat dan Waḥdat al-Wujūd dalam berbagai term tidak hanya menarik pada masanya, namun juga relevan sampai sekarang. Penelitian sebelumnya dengan berbagai disiplin ilmu telah menghasilkan puluhan karya tentang masalah ini. Berdasarkan hasil kajian dengan menggunakan seperangkat metode penelitian, ditemukan bahwa tuduhan yang diajukan oleh Shaykh Nūr al-Din alRanīrī terhadap Hamzah Fansūrī tidak terbukti. Hal ini menunjukkan bahwa mengkategorikan Hamzah Fansūrī dan pemahamannya sebagai sesat adalah tuduhan yang menyesatkan.
\end{abstract}

Keywords: Aceh; tasawuf wujūdiyyat; Hamzah Fansūrī; Nūr al-Dīn al-Ranīrī

\section{A. Pendahuluan}

Aceh sebagai salah satu bagian bumi Nusantara yang terletak di ujung pulau Sumatera pada zaman dahulu berperan penting terutama dalam perkembangan pemikiran Islam umumnya dan tasawuf pada khususnya. Dengan kesultanan Islam yang berkembang maju dan makmur, pada periode pemerintahan Iskandar Muda, Aceh telah berhasil memposisikan dirinya sebagai kutub perdagangan terpenting di wilayah tersebut, bahkan menjadi jem- 
batan penghubung antara Timur dan Barat. Aceh tidak saja maju dalam bidang material, tetapi juga dalam bidang pemikiran Islam dan kehidupan spiritual.

Pada masa antara abad ke-16 dan ke-17, Aceh sedikitnya "melahirkan" empat ulama besar yang berhasil memperkaya wacana tasawuf di Indonesia. Pemikiran-pemikiran mereka masih terlihat pengaruhnya dalam peta pemikiran Islam di Nusantara dewasa ini. Mereka secara berturut-turut adalah: Hamzah Fansūrī (1607 M), Shams al-Dīn al-Sumatrānī (1630 M), Nūr al-Dīn al-Ranīīi (1658 M), dan 'Abd al-Ra’ūfSinkel (1693M).

Keempat tokoh besar tasawuf di atas dilihat dari corak pemahaman tasawufnya terbagi dalam tiga kelompok; Kelompok pertama, diwakili oleh Hamzah Fansūrī dan Shams al-Dīn al-Sumatrānī sebagai kelompok yang dikenal penganut paham tasawuf falsafi. Kelompok kedua, diwakili oleh Nūr al-Dīn alRanīrī yang dikenal sebagai penganut aliran tasawuf sunni. Kelompok ketiga, 'Abd al-Ra'ūf Sinkel yang dikenal sebagai tokoh tasawuf yang akomodatif dan moderat. Dari ketiga kelompok di atas, kelompok pertama dan kedua pada masanya dipenuhi dengan berbagai macam kontroversial bahkan sampai menimbulkan konflik penyesatan yang berkepanjangan.

Hamzah Fansūrī dan muridnya Shams al-Dīn al-Sumatrānī adalah merupakan tokoh tasawuf Wujūdiyyat yang berpengaruh berkat karya-karyanya, baik dalam bahasa Arab maupun bahasa Melayu, dengan murid dan pendukung yang cukup banyak. Di bawah pengaruh dan dominasi intelektual Shams al-Dīn al-Sumatrānī sebagai mufti dan penasehat Sultan Iskandar Muda, aliran Wujüdiyyat berkembang luas. Akan tetapi, pasca wafatnya Shams al-Dīn alSumatrānī dan bergantinya rezim penguasa dari Sultan Iskandar ke Sultan Iskandar Muda (1607- 1636 M) ${ }^{1}$ ke Sultan Iskandar II pengaruh paham tasawuf Wujūdiyyat mulai memudar.

Setelah Sultan Iskandar Muda dan Shams al-Dīn al-Sumatrānī wafat, maka sebagai penggantinya, diangkatlah Sultan Iskandar II menjadi Sultan kerajaan Aceh dengan gelar Sultan Alauddin Ali Mghayat Syah pada tanggal 12 Dzulhijjah tahun 936 H (7 Agustus 1530 M), ${ }^{2}$ dan posisi mufti kemudian dijabat oleh Nūr

\footnotetext{
${ }^{1}$ Denys Lombard, Kerajaan Aceh: Zaman Sultan Iskandar Muda (1607-1636) (Jakarta: Kepustakan Populer Gramedia, 2006), 107.

2J. M. Barwise dan N. J. White, A Traveller's History of Southeast Asia (New York: Interlink Books, 2002), 75 .
} 
al-Dīn al-Ranīī seorang cendekiawan Islam dari Gujarat yang datang ke Aceh pada tahun 1637.3 Posisi strategis ini dimanfaatkannya untuk melancarkan kampanye pemberantasan terhadap apa yang disebutnya tasawuf Wujūdiyyat.

Metode yang digunakan oleh Nūr al-Dīn al-Ranīrī dalam memberantas paham tersebut adalah dengan menggunakan karya tulis dalam bentuk buku, di samping itu, beliau juga melakukan perdebatan dengan para pengikut Hamzah Fansūrī dan Shams al-Dīn al-Sumatrānī. Pada masa itu, tak kurang dari 40 ulama dan ahli tasawuf yang berhasil dihimpun untuk mendiskusikan pemikiranpemikiran Wujūdiyyat. Pada akhirnya Nūr al-Dīn al-Ranīrī memfatwakan bahwa paham Wujūdiyyat dan para pengikutnya adalah murtad yang menurut hukum, halal diperangi jika tidak bertobat dan kembali kepada jalan yang benar. ${ }^{4}$

Akibat dari vonis dan fatwa tersebut, berbagai karya Hamzah Fansūrī dan muridnya Shams al-Dīn al-Sumatrānī dibakar dan para pengikutnya yang setia dikejar-kejar bahkan dibunuh. Di antara yang menjadi korban termasuk saudara kandung Sultan sendiri. Kampanye anti Hamzah Fansūrī demikian banyak memakan korban. ${ }^{5}$

Dua tokoh yakni Hamzah Fansūrī dan Nūr al-Dīn al-Ranīrī merupakan dua tokoh tasawuf yang saling berkaitan dalam sejarah pemikiran Islam di Indonesia. Jika salah satu dari nama mereka disebut, maka orang akan selalu ingat pada nama satu lagi. Kisah dua tokoh ini hampir sama dengan kisah yang terjadi dalam dunia pemikiran Islam yaitu antara al-Ghazālī dan Ibn Rushd atau antara Ibn Taimiyah dengan Ibn 'Arabī.

Hamzah Fansūrī dengan Nūr al-Dīn al-Ranīrī adalah dua tokoh yang saling bertentangan. Nūr al-Dīn al-Ranīī bersikap sangat menentang pendapatpendapat Hamzah Fansūrī, yang menurutnya terdapat kerancuan pada paham yang dianut oleh Hamzah Fansūrī. Menurut Nūr al-Dīn al-Ranīrī, Hamzah Fansūrī telah menyamakan antara Tuhan dengan makhluk-Nya. Pendapat ini menurut Nūr al-Dīn al-Ranīrī tidaklah benar. Dari adanya kesalahan tersebut

${ }^{3}$ M. C. Ricklefs, A History of Modern Indonesia Since c. 1300, 2nd ed. (Stanford: Stanford University Press, 1994), 190.

${ }^{4}$ Syed Muhammad Naquib al-Attas, The Mysticism of Hamzah Fansuri (Kuala Lumpur: University of Malaya Press, 1970), 66.

${ }^{5}$ Ahmad Daudy, Allah dan Manusia dalam Konsepsi Syeikh Nuruddin Ar-Raniry Oakarta: Rajawali Press, 1983), 42. 
maka Nūr al-Dīn al-Ranīrī menganggap paham yang dianut oleh Hamzah Fansūrī termasuk paham yang sesat. Untuk itu demi mencegah paham tersebut berkembang luas maka Nūr al-Dīn al-Ranīrī melakukan pencegahan dengan cara melakukan berbagai macam kritikan terhadap paham tasawuf Hamzah Fansūrī.

Diantara kritikan Nūr al-Dīn al-Ranīrī terhadap Hamzah Fansūrī adalah:

"Dengan meyakini bahwa ruh-ruh dan semua yang ada di alam ini merupakan bagian dari Allah. Karena Allah yang menciptakan segala sesuatu yang akan kembali kepada-Nya. Keyakinan inilah yang dianut oleh Hamzah Fansūrī dan Shams al-Dīn al-Sumatrānī, dan keduanya adalah sesat. Di mana sebagian orang yang meyakini pendapat ini menyamakan antara ciptaan dengan Sang Pencipta dan antara yang membuat dengan yang dibuat'. 6

Kritikan yang dilancarkan oleh Nūr al-Dīn al-Ranīrī tidak hanya dari segi ajaran saja akan tetapi nampaknya ia terkesan ingin menghilangkan ajaran Wujūdiyyat tersebut. Untuk itu dalam tulisan ini dilakukan penelusuran ulang terhadap kritikan Nūr al-Dīn al-Ranīrī atas Hamzah Fansūrī dengan merumuskan pertanyaan: Bagaimana hakikat paham Wujūdiyyat Hamzah Fansūrī; dan mengapa Nūr al-Dīn al-Ranīī menyesatkan paham Wujūdiyyat Hamzah Fansūrî?

\section{B. Hamzah Fansūrī: Biografi, Kehidupan, dan Karya-karyanya}

Menelusuri sejarah kehidupan Hamzah Fansūrī, para sarjana tidak menemukan data yang akurat. Hal tersebut disebabkan tidak adanya sebuah karya awal pun yang menceritakan sejarah kehidupan beliau. Bahkan dalam Hikayat Aceh dan Bustān al-Salāthīn, dua buah kitab yang dipercayai paling lengkap memuat rekaman sejarah Aceh pada abad ke-16 dan ke-17, tidak tertera nama Hamzah Fansūrī. ${ }^{7}$ Dari kondisi ini para peneliti menduga bahwa alasan kenapa nama Hamzah Fansūrī tidak disebut dalam dua buah buku tersebut, salah satu dari peneliti itu adalah Kraemer mengemukakan sebagaimana dikutip oleh Abdul Hadi W. M. bahwa sosok Hamzah Fansūrī ini sering mengembara dan

${ }^{6}$ Nuruddin al-Raniri, Al-Tibyan fi Ma'rifah al-Adyan, (Kuala Lumpur), 26-27, sebagaimana yang dikutip oleh Alwi Shihab, Islam Sufistik; Islam Pertama dan Pengaruhnya hingga Kini di Indonesia (Bandung: Mizan, 2001), 130.

${ }^{7}$ Abdul Hadi Wiji Muthari, Tasawufyang Tertindas: Kajian Hermeneutik terhadap Karya-karya Hamzah Fansuri (Jakarta: Paramadina, 2001), 116. 
jarang sekali berada di Aceh. Akan tetapi sebenarnya, adanya ketidakjelasan mengenai sejarah kehidupan Hamzah Fansūrī tersebut bisa kita lakukan dengan melacak keterangan dari karya-karya yang pernah ditulis olehnya.

Jika melihat dari nama yang disandangnya yakni Hamzah Fansur, maka dapat diperkirakan bahwa ia berasal dari Fansur yakni suatu daerah yang berada di daerah Sumatera. Menurut ketarangan, ia dilahirkan di Syahru Nawi di Siam, kini termasuk wilayah Thailand. Hal tersebut sebagaimana diungkapkan dalam bait Syairnya:

Hamzah berasal dari Fansūrī

Lahir di Syahru Nawi. ${ }^{8}$

Menurut keterangan lain sebagaimana diungkapkan oleh al-Attas, dengan melakukan analisis dari segi bahasa dalam syair tersebut bahwa terdapat keterangan dari kata "empat" dan "asal". Kata "Asal" di situ bukan berarti Hamzah dilahirkan di Fansur, melainkan keluarga, sanak famili dan nenek moyangnya berasal dari Fansūrī. ${ }^{9}$ Keterangan ini ternyata mendapat sanggahan dari Drewes sebagaimana dikutip oleh M. Afif Anshori dengan alasan penyebutan nama-nama daerah lain seperti Kudus, Makkah, Baghdad, dan Shahru Nawi dalam syair-syair Hamzah Fansūrī adalah bagian dari kesan pengalaman beragamanya. ${ }^{10}$

Menurut Afif Anshori bahwa pangkal tolak perbedaan pendapat mengenai tempat kelahiran Hamzah terletak pada perbedaan pemahaman kata "wujūd" dalam bait mendapat wujud di tanah Shahrnawi.11 Menurut al-Attas, kata "wujūd" diartikan dengan "existence". Jika dirujuk dalam bahasa Inggris, memang kata "wujūd" sering diterjemahkan dengan istilah "existence" yang dalam bahasa Indonesia berarti " $a d a$ ". 12

Lebih lanjut, Afif Anshori melakukan elaborasi berkaitan dengan pencarian di mana sebenarnya Hamzah Fansūrī dilahirkan. Afif melakukan elaborasi ber-

${ }^{8}$ Hamzah Fansuri, Ruba'iyat, dalam Syed Muhammad Naquib al-Attas, Tasawwuf a-Fansuri (Kuala Lumpur: University of Malaya Press, 1970), 7; syair tersebut dikutip juga oleh Shihab, Islam Sufistik, 125.

${ }^{9}$ al-Attas, The Mysticism of Hamzah Fansur, 5; M. Afif Anshori, Tasawuf Falsafi, Syaikh Hamzah Fansuri (Yogyakarta: Gelombang Pasang, 2004), 63.

${ }^{10}$ Anshori, Tasawuf Falsafi, 63.

${ }^{11}$ Anshori, Tasawuf Falsafi, 63.

12al-Attas, The Mysticism..., 7. 
awal dari pengertian istilah "wujūd". Menurutnya istilah "wujūd" dalam bahasa Arab mempunyai arti baru yakni "yang ada rupa dan bentuknya (dapat diraba, dilihat, dan sebagainya); benda yang nyata (bukan roh, dan sebagainya); maksud; tujuan. ${ }^{13}$

Berdasarkan pengertian etimologis di atas, kata "wujūd" tidak hanya mengandung pengertian "objektif" tetapi juga "subjektif". Maksud dari "objektif" adalah kata "wujūd" merupakan bentuk mashdar dari wujida, yang berarti "ditemukan". Sedangkan pengertian "subjektif", kata "wujūd" adalah mashdar dari wajada, yang berarti "menemukan". Lebih lanjut uraian pengertian di atas, jika dikaitkan dengan teori Ibn 'Arabi, maka akan jelas pengertiannya. Ternyata, pengertian pertama, kata "wujūd" memiliki unsur ontologis, yakni wujud Tuhan. Sedangkan arti kedua, yang mengandung aspek epistimologis, kata "wujūd" mengandung pengertian "menemukan" Tuhan, atau merasakan kehadiran Tuhan sebagai pengalaman rohani. ${ }^{14}$

Dari pengertian di atas, Afif Anshori menyimpulkan bahwa Hamzah Fansūrī dilahirkan di Fansur (Barus), sedangkan Shahrunawi adalah tempat pertama kali ia menemukan atau memperoleh pengalaman rohani tentang Tuhan. ${ }^{15}$ Pendapat tersebut nampaknya mendapatkan penguat dari ungkapan Ali Hasymy yang dikutip oleh Zakaria Ahmad. ${ }^{16}$

Kota Fansur, adalah sebutan lain dari Barus yang biasa disebut oleh orang Arab. Secara geografis, Fansur berada di pesisir pantai Barat Sumatra Utara dan berada antara kota Sibolga dan Singkel. Keberadaan daerah ini sangat tua, setua ketika kapal-kapal asing beribu tahun sebelum Masehi singgah mencari kapur barus di sana. Lewat pelabuhan Barus, agama Islam dan Kristen awal mula dikenalkan ke seluruh Nusantara.

Dilihat dari sejarahnya, Pelabuhan Barus adalah satu-satunya kota di Nusantara yang namanya telah dikenal sejak awal abad Masehi dan tertera di literatur-literatur dalam berbagai bahasa, seperti dalam bahasa Yunani, Suriah, Armenia, Arab, India, Tamil, China, Melayu, dan Jawa. Hal tersebut bisa dilihat ditemukannya sebuah peta kuno yang dibuat oleh Claudius Ptolemaus, seorang

\footnotetext{
13Pusat Pembinaan dan Pengembangan Bahasa (Tim Penyusun Kamus), Kamus Besar Bahasa Indonesia (Jakarta: Depdikbud \& Balai Pustaka, 1980), 1013.

${ }^{14}$ Anshori, Tasawuf Falsafi, 64-5

${ }^{15}$ Anshori, Tasawuf Falsafi, 66.

16Zakaria Ahmad, Sekitar Kerajaan Atjeh dalam Tahun 1520-1675 (Medan: Monora, 1972), 110.
} 
gubernur dari Kerajaan Yunani yang berpusat di Alexandria, Mesir, pada abad ke-2. Di peta itu disebutkan, bahwa di pesisir barat daerah Sumatera terdapat sebuah bandar niaga bernama Barousai (Barus) yang menghasilkan wewangian dari kapur barus. Diceritakan, dalam naskah tersebut bahwa kapur barus yang diolah dari bahan kayu kamfer dari Barousai itu adalah merupakan salah satu bahan pembalseman mayat pada zaman kekuasaan Firaun sejak Ramses II, atau sekitar 5.000 SM.

Berdasakan buku Nuchbatuddar tulisan al-Dimasqi, disebutkan bahwa Kota Barus sejak itu sudah dikenal sebagai pintu masuk agama Islam sekitar abad ke-7. Sebagai buktinya bahwa di daerah Barus terdapat areal pemakaman tua yang disebut dengan pemakaman Mahligai Barus, yang di batu nisannya tertulis Syekh Rukunuddin wafat tahun 672 Masehi atau 48 Hijriah. Penemuan areal makam tersebut menguatkan adanya komunitas Muslim di daerah ini pada era itu.

Bukan saja Islam yang pertama masuk melalui daerah ini, akan tetapi pihak Kristen mempercayai bahwa Barus merupakan pintu masuk agama Kristen di nusantara. Menurut catatan bahwa sejak tahun $645 \mathrm{M}$ di daerah Barus telah masuk agama Kristen dari sekte Nestorian. ${ }^{17}$ Keyakinan tersebut tentu didasarkan pada bukti yang kuat. Salah satu buktinya adalah adanya sebuah catatan pana naskah kuno yang ditulis oleh Shaykh Abu Salih al-Armini. Keyakinan dugaan tersebut juga diperkuat oleh catatan penjelajah dari Armenia, Mabousahl yang mencatat bahwa pada abad ke-12 telah terdapat Gereja Nestorian. Bukti lainnya sebagai penguat bahwa Barus adalah pintu masuk agama Kristen di Nusantara adalah dengan ditemukannya hasil penggalian arkeologi yang dilakukan oleh Daniel Perret bersama tim dari Ecole francaise d'Extreme-Orient (EFEO) Perancis bekerja sama dengan peneliti dari Pusat Penelitian Arkeologi Nasional (PPAN) di Lobu Tua, Barus. Dari hasil penelitian ditemukan adanya bukti bahwa pada antara abad ke-9 dan abad ke-12 terdapat perkampungan multietnis dari suku Tamil, China, Arab, Aceh, Jawa, Batak, Minangkabau, Bugis, Bengkulu, dan sebagainya di kota Barus. Perkampungan multi etnis tersebut dikabarkan sangat makmur, hal itu terlihat dengan ditemukannya barang-barang hasil galian yang mempunyai kualitas tinggi. ${ }^{18}$ 2008).

${ }^{17}$ Edward Simanungkalit, "Barus: Kota Prasejarah Nusantara," Majalah Kirana (Surabaya,

18Silvita Agmasari, “Temuan Ahli Antropologi di Balik Mantra Misterius dari Barus," National Geographic Indonesia, 2017, http://nationalgeographic.grid.id/read/13309094/temuan-ahliantropologi-di-balik-mantra-misterius-dari-barus, diakes 2 Januari 2018. 
Bukti lainnya bahwa di Barus pada tahun $1872 \mathrm{M}$, pejabat Belanda yakni G.J.J. Deutz, menemukan batu bersurat tulisan Tamil yang kemudian pada 1931 M, batu bersurat tersebut diterjemahkan oleh Prof. Dr. K. A. Nilakanta Sastri dari Universitas Madras, India. Hasil terjemahannya diketahui bahwa batu bertulis itu bertahun Saka 1010 atau 1088 M di zaman pemerintahan Raja Cola yang menguasai wilayah Tamil, India Selatan. Dalam batu bertulis tersebut antara lain menyebutkan adanya perkumpulan dagang suku Tamil yang dihuni oleh sekitar 1.500 orang. Dalam batu bertulis itu juga disebutkan bahwa perkampungan tersebut memiliki pasukan keamanan, aturan perdagangan, dan ketentuan lainnya yang lebih modern. Namun, Lobu Tua yang merupakan kawasan multietnis di Barus tersebut kemudian ditinggalkan secara mendadak oleh penghuninya pada awal abad ke-12 sesudah kota tersebut diserang oleh kelompok yang dinamakan Gergasi. Setelah ditinggalkan, Kota Barus pun berganti penghuni, yang kemudian dihuni oleh orang-orang suku Batak. ${ }^{19}$

Sampai abad ke-16 M, kota Barus masih merupakan pelabuhan dagang yang sangat penting yang banyak dikunjungi para saudagar dan musafir dari berbagai negara. ${ }^{20}$ Akan tetapi, sangat disayangkan kota Barus yang sebelumnya merupakan kota makmur harus mengalami perubahan yang menyedihkan pada permulaan abad ke-17. Pamor kota ini merosot diakibatkan oleh maraknya perkembangan kerajaan Aceh Darussalam yang berkeinginan menjadi penguasa mutlak di seluruh pesisir Sumatra. Di bawah pemerintahan Sultan Iskandar Muda, Aceh berhasil menaklukkan kerajaan Barus dan memaksanya untuk tunduk pada pemerintahan Aceh. ${ }^{21}$ Dampak dari penaklukan itu, pihak kerajaan Aceh membuat kebijakan memperkecil peranan Barus-baik sebagai pusat perniagaan maupun kebudayaan.22 Kehancuran Barus semakin nyata ketika pada tanggal 29 Desember 1948, kota Barus dibumihanguskan oleh pejuang kemerdekaan Indonesia. Hal ini dilakukan karena ada dugaan bahwa kolonial Belanda yang saat itu telah menguasai Sibolga dikabarkan akan menguasai Barus. Sejak saat itu, kota Barus yang masyhur dan terkenal itu kemudian

${ }^{19}$ Claude Guillot, Lobu Tua: Sejarah Awal Barus, terj. Daniel Perret (Jakarta: Yayasan Pustaka Obor Indonesia, 2002).

${ }^{20}$ Abdul Hadi Wiji Muthari, Hamzah Fansuri: Risalah Tasawuf dan Puisi-puisinya (Bandung: Mizan, 1995), 9.

21Muthari, Hamzah Fansuri, 11.

${ }^{22}$ Lombard, Kerajaan Aceh, 110-11. 
menjadi pudar dan hanya dikenal menjadi kecamatan kecil yang berada di daerah pinggiran yang hampir-hampir tak tersentuh roda pembangunan. Sejak saat itu, banyak sebagian warganya meninggalkan desa, mencari mata pencaharian yang lebih layak di luar daerah Barus.

Pada akhirnya, kota Barus yang dahulunya maju, ramai dikunjungi oleh para pendatang dari luar negeri, kini hanya menjadi kota sunyi dan hanya pantas dihuni oleh para nelayan kecil saja. Kemegahan yang sebelumnya bersinar, kini harus redup bahkan pupus. Untung saja, di saat Barus mulai dilupakan orang, muncullah seorang tokoh yang kembali memperkenalkan kota ini seperti masa-masa kejayaannya. Menurut Valentijn seorang sarjana Belanda yang mengunjungi Barus pada tahun 1706 yang dikutip oleh Abdul Hadi W.M., menulis dalam sebuah karyanya:

"Seorang penyair Melayu, Hamzah Pansur... yakni seorang yang sangat terkemuka di lingkungan orang-orang Melayu oleh karena syair-syair dan puisi-puisinya yang menakjubkan, membuat kita karib kembali dengan kota tempat lahir sang penyair. Bilamana di dalam puisi-puisinya yang agung dia mengangkat naik dari timbunan debu kebesaran dan kemegahan masa lampau kota itu dan mencipta kembali masa-masa gemilang dari kebesarannya."23

Selanjutnya, mengenai kapan atau tahun berapa Hamzah Fansūrī hidup ternyata para sarjana pun memperdebatkannya. Drewes yang mengutip statemen Snouck Hurgronje, mengemukakan bahwa usia Hamzah Fansūrī lebih tua dari Shams al-Dīn al-Sumatrānī, oleh sebab itu Hamzah Fansūrī diperkirakan hidup pada akhir abad ke-16 M.24 Menurut H. Kraemer, Hamzah Fansūrī hidup setelah tahun 1636 dan bukan sebagai pendahulu, melainkan sezaman dengan Shams al-Dīn al-Sumatrānī. Menurut keterangan, antara Hamzah Fansūrī dan Shams al-Dīn al-Sumatrānī selisih usia sekitar hanya sepuluh tahun. ${ }^{25}$ Pendapat tersebut mendapat dukungan dari Winstead dan Harun Hadiwijono. ${ }^{26}$ Argumentasi yang dibangun oleh Kelompok ini berdasarkan kata "Marhum Makuta Alam" yang terdapat dalam syair Hamzah Fansūrì:

\footnotetext{
23Muthari, Hamzah Fansuri, 12.

${ }^{24}$ Anshori, Tasawuf Falsafi, 67.

25Muthari, Hamzah Fansuri, 13.

26Muthari, Hamzah Fansuri, 13.
}

JURNAL THEOLOGIA — Volume 29, Nomor 1, Juni 2018 
"Berkatalah faqiir dha' if (lemah) jang boediman,

Amat adjaib maqām di loear poen: ada ia chabar

Di Tanah Djawa, dari Atjeh Marhoem Makota 'Alam

Dihimpoenkan sekalian sjarat dinazarkan

Kepada rasanja jang ni'mat ditoeroenkan". 27

Kata "Marhoem Makota 'Alam" yang terdapat dalam syair itu adalah gelar yang disandang oleh Sultān Iskandar Muda, yang memerintah Aceh pada tahun 1606-1636. ${ }^{28}$ Dari data ini, maka diasumsikan bahwa Hamzah Fansūrī hidup pada masa Sultān Iskandar Tsāni.

Berbeda dengan pendapat di atas, al-Attas bahkan menolak pendapat tersebut dengan alasan bahwa syair tersebut tidak dapat dijadikan rujukan karena syair tersebut terdapat interpolasi (penambahan/penyisipan) kalimat. Lebih lanjut ia mengatakan bahwa Hamzah Fansūrī hidup pada masa Aceh diperintah sebelum Sultān Iskandar Muda, yakni Sultān Ala al-Dīn Ri'ayat Syah al-Mukammil (1571-1607 M). Argumentasi yang disodorkan adalah syair yang berjudul "Ikatan-ikatan 'Ilm al-Nisä’”.

"Hamba mengikat sjair ini

Di bawah hadharat radja jang wali

Karuni Allah akan toehan kami..."29

Menurut keterangan al-Attas, Syair ini merupakan pesanan Sang Sultān, atau paling tidak, Hamzah Fansūrī sendiri yang menghadiahkan pada Sultān. ${ }^{30}$

Adapun istilah "Raja jang wali" dalam syair tersebut tertuju pada Sultān 'Ala al-Din Ri'ayat Syah, yang dikenal sebagai Syah Alam. ${ }^{31}$

Mengenai perjalan hidupnya tidak dapat ditemukan dengan jelas, dimana dia hidup. Akan tetapi jika kita melihat dalam karya-karyanya, Hamzah Fansūrī adalah seorang ulama yang pada usia mudanya banyak melakukan perjalanan

27J. Doorenbos, De Geschriften van Hamzah Pansoeri (Leiden: N.V.v.h. Batlejee dan Tremptra, 1933); dikutip oleh Anshori, Tasawuf Falsafi..., 68.

${ }^{28}$ A. Hasymy, Sejarah Masuk dan Berkembangnya Islam di Indonesia (Bandung: Al-Ma'arif, 1993), 240.

29Doorenbos, De Geschriften, dikutip oleh Anshori, Tasawuf Falsafi, 69.

${ }^{30}$ Anshori, Tasawuf Falsafi, 69-70.

${ }^{31}$ R. Housen Djajadiningrat, Kesultanan Aceh: Suatu Pembahasan tentang Sejarah Kesultanan Aceh Berdasarkan Bahan-bahan yang Terdapat dalam Karya Melayu, terj. Teuku Hamid (Banda Aceh: Depdikbud \& Proyek Pengembangan Permesiuman Daerah listimewa Aceh, 1982), 213. 
dan mengunjungi berbagai negara. Dalam salah satu karyanya "Syair Dagang", Hamzah Fansūrī menceritakan bahwa ia telah menjadi yatim piatu semenjak kecil. Kedua orang tuanya meninggalkannya dalam keadaan menderita, sebagaimana dalam syairnya ia mengaku sebagai orang yang miskin, hina, bebal, dha'îf dan sebagainya. Ia mengaku berasal dari masyarakat biasa. Kondisi tersebut justru membuat Hamzah Fansūrī bersemangat untuk berjuang berkelana mencari ilmu sampai ke berbagai negara, terutama negara-negara Timur Tengah.

\section{"Yā Ilahi yā wujūdi bi al-dawān (kekal)}

Ukhruj-kan (keluarkan) Hamzah daripada pangkat awam (orang awam)

Peliharakan ia daripada kerja yang haram (dilarang)

Supaya dapat ke där al-Salām (tempat yang selamat)"

Syair yang lain:

"Hamzah Fansūrī terlalu Bebal (dungu/bodoh)

Disangka dunyā nin manisnya kekal

Terlalu ghāfil (lalai)mencari bekal

Tidak shakk (ragu) esok akan menyesal"

Dalam menuntut ilmu, Hamzah Fansūrī memulainya di kampung halamannya di kota Barus. Ketika itu kota Barus telah mempunyai lembaga pendidikan, khususnya sekolah-sekolah agama. Di sekolah tersebut orang dapat mempelajari berbagai bahasa asing, khususnya bahasa Arab dan Persia (Iran sekarang). ${ }^{32}$ Kondisi pendidikan tersebut membuat Hamzah Fansūrī mahir dalam bahasa Arab dan Persia. Di tempat itu pula Hamzah Fansūrī sebelum berangkatnya ke luar negeri mempelajari berbagai disiplin ilmu seperti tasawuf, kesusastraan, dan ilmu-ilmu agama lainnya.

Ketika ilmu yang dipelajarinya di Barus merasa cukup, ia pun pergi ke luar negeri dengan tujuan yang sama, diantara tempat yang ia kunjungi antara lain; Makkah, Madinah, Bagdad, Thailand (Shahrnawi), Malaya, dan Jawa. ${ }^{33}$ Kunjungannya ke berbagai negera membuatnya menjadi ulama, penyair, dan sufi yang masyhur.

Mengenai karya-karya Hamzah Fansūrī, menurut Alwi Shihab sejauh yang didapatkannya ada tiga yakni Asrār al-'Árifin, Sharb al-'Āshiqīn, dan al-Muntahî. ${ }^{34}$

\footnotetext{
32Muthari, Hamzah Fansuri, 10.

33al-Attas, The Mysticism, 8.

${ }^{34}$ Shihab, Islam Sufistik,126.
} 
Abdul Hadi Wiji Muthari menambahkan diantara karya-karya Hamzah Fansūrī yang telah dijumpai ialah tiga risalah tasawuf dan 33 ikat-ikatan syair (setiap ikat-ikatan terdiri dari 13,15 atau 19 bait syair). ${ }^{35}$ Abdul Hadi sendiri menambahkan meskipun ia sendiri dan para peneliti lain meragukannya bahwa Sya'ir Perahu, Bahr al-Nisä', Sya'îr Dagang diduga adalah buah karyanya. ${ }^{36}$ Berbeda dengan M. Afif Anshori dengan dukungan Karel A. Steenbrink meyakinkan bahwa Sya'ir Perahu, Sya'ir Dagang, Syai'ir Burung Pingai adalah buah karya dari Hamzah Fansūrī, akan tetapi ia tidak memasukan Baḥr al-Nisā' sebagai karya Hamzah Fansūrīi. 37

\section{Sharb al-'Āshiqīn}

Kitab ini menurut keterangan Abdul Hadi Wiji Muthari, mempunyai nama lain Zinat al-Wahidin atau Zinat al-Muwaḥhidīn yang diperkirakan ditulis pada akhir abad ke-16, ketika perdebatan sengit tentang wujüdiyyat sedang berlangsung di Aceh, yang melibatkan ahli-ahli tasawuf, ushuluddīn, dan ilmu fiqih terkemuka pada waktu itu. Perdebatan tentang Wujūdiyyat ini lebih dikenal dengan perdebatan al-a'yān al-thābitạh (esensi segala sesuatu) yang merupakan persoalan sentral di dalam ajaran Wujūdiyyat. ${ }^{38}$ Ajaran Wujüdiyyatyang menjadi perdebatan pada waktu itu dibawa oleh dua orang ulama dari Makkah, yaitu Abu al-Kahhar ibn Syeikh Ibn Hajār pengarang kitab Saif al-Qāti', serta Shaykh Yamani. Dalam perdebatan itu, mereka tidak dapat mempertahankan argumentasinya, sehingga keduanya harus angkat kaki dan kembali ke Makkah. ${ }^{39}$ Dalam perdebatan itu, menurut Abdul Hadi, Hamzah Fansūrī dan beberapa muridnya ikut terlibat dalam perdebatan yang menegangkan tersebut.

Naskah kitab Sharb al-'Ashiqin yang ada adalah koleksi Snouck Hurgronje yang ditemukannya di Aceh pada akhir abad ke-19 dan sekarang tersimpan di museum perpustakaan Leiden (MS Cod.Or. 7291). Naskah yang lebih lengkap di jumpai di Banten dan disimpan di tempat yang sama (MS.Cod.Or. 2016). Pada

35Muthari, Hamzah Fansuri, 13.

36Muthari, Tasawufyang Tertindas, 146-55; 171-79.

${ }^{37}$ Anshori, Tasawuf Falsafi, 74.

38Muthari, Hamzah Fansuri, 17-8.

${ }^{39}$ Muhammad Said, Aceh Sepanjang Abad (Medan: PT. Percetakan dan Penerbitan Pustaka, 1981), 251-252. 
tahun 1933 Doorenbos menyalin risalah ini dengan mempergunakan dua naskah tersebut, karena naskah yang ditemukan di Aceh tidak lengkap, maka hasil penyalinan itu tidak memuaskan al-Attas sehingga mendorongnya untuk menyalin dan menyunting lagi serta menerjemahkannya ke dalam bahasa Inggris. ${ }^{40}$

Pada akhir abad ke-17, kitab ini diterjemahkan ke dalam bahasa Jawa bersamaan dengan tersebarnya paham Wujūdiyyat di Jawa. Naskah versi terjemahan ini ditemukan di Banten, kepunyaan Sultān Abu al-Mahasīn Zayn al'Abidīn raja Banten tahun 1690-1733 M.41

Jika dilihat dari kandungannya, kitab ini adalah ringkasan ajaran Wahdat alWujūd Ibn 'Arabī, Sadr al-Dīn al-Qunawi, dan 'Abd Karīm al-jillī, dan cara mencapai makrifät, kemungkinan mengikuti amalan tarekat Qadiriyah yang dianut oleh Hamzah Fansūrī. Dilihat dari sistematikanya, kitab ini memuat tujuh bab dan uraiannya tentang tasawuf sangatlah ringkas. 42

Bab 1, 2, 3 dan 4 menguraikan tahap-tahap ilmu suluk yang terdiri dari syari'at, tarekat, hakikat, dan makrifat. Bab 5 menguraikan tajallī Zat Tuhan Yang Maha Tinggi. Dalam bagian ini diuraikan asas-asas ontologi Wujūdiyyat. Bab 6 menguraikan sifat-sifat Allah. Bab 7 menguraikan 'ishq dan sukr (kemabukan mistik).43

Kitab ini ditulis dengan tujuan sebagai pedoman bagi pemula dalam ilmu sulūk. Sehingga uraian dalam kitab ini ringkas, jelas, dan bahasanya sangat mudah dicerna dan terpelihara. Dalam kitab ini, Hamzah Fansūrī menganjurkan kepada seorang ahli tarikat untuk tidak meninggalkan syari'at, karena syari'at ialah permulaan tarekat. Intisari atau makna keruhanian syari'at ialah kewajiban berbuat kebajikan di dunia dan menjauhkan diri dari segala perbuatan jahat. Wujud lahiriyahnya berupa amalan rukun Islam yang lima.44

\section{Asräral-'Ārifin}

Kitab ini merupakan karya prosa Hamzah Fansūrī yang paling panjang. Karya ini dilihat dari tampilan isinya sangatlah unik, tidak ada duanya dalam

\footnotetext{
40Muthari, Tasawufyang Tertindas, 146.

41Muthari, Tasawufyang Tertindas, 176.

42Muthari, Tasawufyang Tertindas, 176

43Muthari, Tasawufyang Tertindas, 176.

${ }^{44}$ Hamzah Fansuri, Sharb al-'Āshiqinn, dikutip oleh Muthari, Tasawufyang Tertindas, 147.
} 
khazanah sastra Melayu. Menurut Abdul Hadi W. M., penulis kitab ini terilhami oleh Sawānih karya Ahmad al-Ghazālī, Tarjuman al-'Ashwāq karya Ibn 'Arabī, Lama'at karya al-'Irāqi. Kesemua kitab itu merupakan risalah-risalah tasawuf yang uraiannya diselingi dengan puisi atau merupakan penafsiran atas puisi karya penulisnya sendiri. Jika dibandingkan dengan kitab Hamzah Fansūrī lainnya, maka kitab ini merupakan kitabnya yang terbesar dan orisinil. 45

Dalam kitab ini Hamzah Fansūrī menurunkan lima belas syair karangannya dan ditafsirkannya sendiri serta ditelaah baris demi baris. Telaah-telaah tersebut merupakan uraian yang panjang mengenai doktrin metafisika atau ontologi Wujūdiyyat.

\section{Al-Muntahī}

Risalah yang ketiga ini merupakan karya Hamzah Fansūrī yang paling ringkas tetapi padat dan sangat dalam kandungan isinya. Risalah ini menurut cerita ditemukan dalam dua versi, yaitu versi Melayu dan Jawa yang merupakan terjemahan dari naskah aslinya. Versi Melayu ditemukan mengandung dua naskah dan versi Jawa ditemukan satu naskah di Banten, milik Sultān Abu alNasr 'abd al-Qahhār alias Sultān Haji (w. 1687 M). Teks yang ditemukan di Melayu tidak lengkap dan tulisannya tidak jelas. Teks ini sekarang tersimpan di Perpustakaan Leiden (MS.Cod.Or. 5176 I dan II. Kitab ini sudah diterjemahkan ke dalam bahasa Inggris oleh Syed M. Naquib al-Attas. ${ }^{46}$

Secara ringkas, kitab ini membicarakan: 1) Tentang kejadian atau penciptaan alam semesta sebagai panggung manifestasi Tuhan dan KemahakuasaanNya. 2) Tentang bagaimana Tuhan memanifestasikan Diri-Nya dan bagaimana alam semesta dipandang dari sudut pemikiran ahli-ahli makrifat, serta mengenai sebab pertama segala kejadian. 3) Tentang bagaimana seseorang itu dapat kembali lagi ke asalnya, yaitu kepada keadaan "kanz makhfi" (perbendaharaan tersembunyi). ${ }^{47}$

Dalam kitab ini Hamzah Fansūrī banyak mengambil rujukan berupa sajaksajak al-'Iraqi dalam kitabnya Lama'at.88 Menurut keterangan Alwi Shihab kitab

\footnotetext{
45Muthari, Tasawufyang Tertindas, 152.

46Muthari, Tasawufyang Tertindas, 155.

47Muthari, Tasawufyang Tertindas, 157.

48Muthari, Tasawufyang Tertindas, 157.
} 
al-Muntahī inilah yang dijadikan "amunisi" atau sasaran kritik oleh Shaykh Nūr al-Dīn al-Raniri di dalam membabat habis paham Wujūdiyyat di Aceh. ${ }^{49}$

\section{Nūr al-Dīn al-Ranīrī: Kehidupan dan Karya-karyanya}

Kajian mengenai Shaykh Nūr al-Dīn al-Ranīrī (selanjutnya ditulis al-Ranīī) ternyata cukup ramai dilakukan baik itu oleh para sarjana luar (misal: P. Voorhoeve, G.W.J. Drewes, C.A.O. Van Nieuwenhuijze, Syed Muhammad Naquib al-Attas) maupun dalam negeri (misal: R.H. Djajadiningrat, Ahmad Daudy, Tujimah, Azyumardi Azra). Namun pun begitu kajian suatu tokoh yang menyangkut tentang kehidupan dan pemikirannya ternyata tidak pernah mencapai kata sepakat dan final. Atas dasar itu penelitian ini kembali dilakukan dengan tujuan memperkaya dan melengkapi kajian serupa.

Al-Ranīrī mempunyai nama lengkap Nūr al-Dīn Muhammad bin 'Ali bin Hasan al-Hāmid (atau al-Humayd) al-Syāfi'ī al-Asy'āri Al-Ranīrī,50 dilahirkan dalam keluarga Quraisy di Ranīr atau Randir, suatu bandar yang letaknya tidak seberapa jauh dari Surat, Gujarat, India. ${ }^{51}$ Mengenai tahun kelahirannya sampai saat ini belum dikatahui secara pasti, akan tetapi menurut perkiraan kemungkinan besar ia dilahirkan menjelang akhir abad ke-16. ${ }^{52}$ Sedangkan waktu meninggalnya tercatat pada 22 Zulhijjah 1096 H/21 September 1658 M di India. ${ }^{53}$ Al-Ranīrī dilahirkan dari Ibunda seorang keturunan Melayu dan Ayah keturunan Gujarat, India. Menurut sumber lain sebagaimana diungkapkan oleh Azyumardi Azra, ayahnya berasal dari keluarga imigran Hadhrami yang mempunyai tradisi berpindah ke Asia Selatan dan Asia Tenggara. ${ }^{44}$ Berbeda dengan pendapat di atas, Abdullah Arif berpendapat bahwa ayah al-Ranīī keturunan Arab Quraisy kelahiran India, dan Ibunya seorang muslimat bangsa India. ${ }^{55}$

49Shihab, Islam Sufistik,131-132.

${ }^{50}$ Azyumardi Azra, Jaringan Ulama Timur Tengah dan Kepulauan Nusantara Abad XVII dan XVIII, 4 ed. (Bandung: Mizan, 1998), 169.

${ }^{51}$ Nuruddin al-Raniri, Bustān al-Salāțin fi Dhikr al-Awwalīn wa 'l-Ākhirīn, terj. T. Iskandar (Kuala Lumpur: Dewan Bahasa dan Pustaka, 1966), 2.

${ }^{52}$ Azra, Jaringan Ulama, 169.

${ }^{53}$ Ahmad Rifa'i Hasan, Warisan Intelektual Islam Indonesia; Telaah Atas Karya-karya Klasik (Bandung: Mizan, 1987), 22; Daudy, Konsepsi Syeikh Nuruddin, 47; Anshori, Tasawuf Falsafi, 191-192.

${ }^{54}$ Azra, Jaringan Ulama, 169.

${ }^{55}$ Abdulllah Arif, "Syaikh Nūr al-Dīn al-Ranīrī Ulama/Politikus Abad XVII," in Tokoh-tokoh Sastra Melayu Klasik, ed. Muhammad Daud Mohammad (Kuala Lumpur: Dewan Bahasa dan Pustaka Kementrian Pendidikan Malaysia, 1987), 86; Anshori, TasawufFalsafi, 192. 
Karier pendidikannya dimulai di Ranir, kemudian melanjutkan ke daerah Tarim (Arab Selatan) yang termasuk wilayah Hadramaut pada tahun $1030 \mathrm{H}$ (1621 M). Lamanya masa studi pada fase ini tidak ditemukan keterangan berapa lama ia menghabiskan waktu di sana dan siapa saja guru-gurunya, apakah alRanīrī selama rentang studi di wilayah tersebut pernah pulang ketempat kelahirannya. Pertanyaan-pertanyaan itu sampai saat ini masih belum ditemukan jawabannya.

Setelah menuntut ilmu di Tarim, kemudian ia pergi ke Haramayn dalam rangka menunaikan ibadah haji dan ziarah ke makan Nabi Muhammad. Menurut keterangan al-Hasani sebagaimana yang dikutip oleh Azyumardi Azra, ia berada di Makkah dan Madinah pada tahun 1030 H/1620 M atau 1031 H/1621 M.56 Dari kondisi itu, maka sangat dimungkinkan al-Ranīrī menjalin hubungan dengan murid-murid dan jamaah haji dari jawi sebelum kembali ke Gujarat. ${ }^{57}$

Adapun guru al-Ranīīi yang paling berjasa menjadikan al-Raniri seorang ulama yang mumpuni adalah Abu Ḥafș 'Umār bin 'Abdullāh Ba Syaybān alTarimi al-Haḍrāmi (w. 1066 H/1656 M), yang dikenal di wilayah Gujarat sebagai Sayyid 'Umār al-Aydarus. ${ }^{58}$ Dari ulama inilah kemudian Al-Ranīrī mendapatkan ijazah tarekat Rifä’iyah. ${ }^{59}$ Di samping ijazah tarekat Rifā’iyah yang ia sandang, ia juga mendapat dan mempunyai silsilah dari tarekat Aydarusiyyah ${ }^{60}$ dan tarekat Qadiriyah. ${ }^{61}$

Setelah mempelajari berbagai disiplin ilmu dan menyandang tiga ijazah tarekat, kemudian ia berkunjung ke tanah Melayu. Kedatangannya ke Melayu untuk mengikuti jejak pamannya Shaykh Muhammad Zailani Ibn Hasan yang berkunjung ke Aceh lima puluh tahun sebelumnya. Al-Ranīrī tiba di Aceh pada 6 Muharram 1047 H atau 3 Mei 1637 M, yaitu pada masa pemerintahan Sultān Iskandar II.62 yang merupakan menantu dari Sultān Iskandar Muda. ${ }^{63}$ Pada tahun itu pula al-Ranīrī diangkat oleh Sultān Iskandar II menjadi Shaykh al-Islam

56Azra, Jaringan Ulama, 171-172.

${ }^{57}$ Azra, Jaringan Ulama, 172.

${ }^{58}$ Azra, Jaringan Ulama, 172,

59Shihab, Islam Sufistik; 51.

${ }^{60}$ Lihat dalam karyanya Jawāhir al-'Ulūm fí Kasyfal-Ma'lūm

${ }^{61}$ Lihat dalam karyanya Safināt al-Najah karya Syaikh Yusuf al-Maqassari.

62al-Raniri, Bustān al-Salāțin, 2; Daudy, Konsepsi Syeikh Nuruddin, 38.

${ }^{63}$ Daudy, Konsepsi Syeikh Nuruddin, 39. 
atau setingkat mufti. ${ }^{64}$ Dari keterangan tersebut, maka bisa diasumsikan bahwa al-Ranīī sebelumnya pernah datang ke Aceh. Ada beberapa argumentasi yang bisa memperkuat asumsi tersebut, diantaranya: pertama, sebelum ia datang ke Aceh, ia telah mahir berbahasa Melayu seperti yang terlihat pada karya-karyanya yang ditulis sebelum ia datang ke Aceh seperti kitab al-Shirāt al-Mustaqim yang ditulis pada tahun 1633 M. Kedua, karya yang dihasilkan oleh al-Ranīī berjumlah 29-30 judul buku. Hal tersebut tidak mungkin semuanya ditulis oleh al-Ranīī selama tujuh tahun ia menetap di Aceh. Karena disamping menulis, ia juga bertugas sebagai mufti kerajaan dan penasihat Sultan.

Jika asumsi di atas benar, maka pertanyaannya, mengapa ketika al-Ranīrī datang untuk pertama kali sebelum tahun $1637 \mathrm{M}$, ia tidak muncul atau dalam arti mendapat sambutan dari pihak penguasa pada waktu itu? Jawaban atas pertanyaan tersebut dapat diselesaikan dengan cara melihat kondisi sejarah sosial politik pada waktu itu.

Pada masa pemerintahan Sultān Iskandar Muda, jabatan mufti pada waktu itu dipegang oleh Shams al-Dīn al-Sumatrānī yang mengajarkan doktrin Wujūdiyyat. Pada masa al-Sumatrānī inilah, paham Wujūdiyyat berada pada puncak kejayaannya. Kondisi itu menurut al-Ranīrī dirasa tidak tepat untuk menentang tatanan politik dan keagamaan yang berkuasa. Al-Ranīrī merasa perlu menunggu situasi yang tepat melancarkan pahamnya. Alasan yang kedua, adanya perbedaan mazhab antara al-Ranīī dengan penguasa pada waktu itu. 65

Barulah pada saat Shams al-Dīn al-Sumatrānī meninggal dan diikuti oleh meninggalnya Sultān Iskandar Muda yang kemudian digantikan dengan Sultān Iskandar Tsani (II), al-Raniri kembali lagi ke Aceh yakni pada tahun 1637. Menurut keterangan lain, datangnya al-Ranīrī ke Aceh bukan atas kemauannya sendiri akan tetapi ia dipanggil oleh Sultān Iskandar Tsani untuk diangkat menjadi mufti.66 Pada saat itu gendang permusuhan antara al-Ranīī dan pengikut paham Wujūdiyyat Hamzah Fansūrī dan muridnya Shams al-Dīn al-Sumatrānī dikumandangkan.

Pada saat al-Ranīrī menjabat sebagai mufti, ia tidak menyia-nyiakan kesempatan tersebut untuk digunakan dalam menyerang paham Wujūdiyyat yang dianggapnya sesat. Untuk menyerang paham Wujūdiyyat tersebut, ia mengguna-

${ }^{64}$ Azra, Jaringan Ulama, 177.

65Shihab, Islam Sufistik, 51.

66Shihab, Islam Sufistik, 51-52.

JURNAL THEOLOGIA — Volume 29, Nomor 1, Juni 2018 
kan empat bentuk cara: pertama, ia menyerang dengan cara membuat buku yang berisi kecaman disertai argumentasi terhadap paham Wujūdiyyat. Kedua, ia melakukan perdebatan secara terbuka dengan para pengikut paham Wujüdiyyat. Ketiga, ia menggunakan alat legitimasi mufti untuk mengeluarkan fatwa tentang sesatnya ajaran Wujūdiyyat yang dibawa oleh Hamzah Fansūrī dan Shams al-Dīn al-Sumatrānī. Keempat, ia mengusulkan kepada penguasa atau Sultān yang berkuasa pada waktu itu untuk menghukum mati bagi masyarakat yang tidak mengikuti anjuran dari al-Ranīī untuk bertaubat dan meninggalkan paham Wujūdiyyat tersebut, disamping itu ia juga menganjurkan untuk membakar kitab-kitab yang dijadikan rujukan oleh mereka.

Selama masa jabatan sebagai mufti yakni sekitar tujuh tahun, al-Ranīrī banyak mengeluarkan fatwa keagamaan, seperti larangan bagi masyarakat mencaci Mu'awiyyah dan anaknya, Yazid.67 Fatwa tersebut diperuntukkan sehubungan semakin menguatnya ajaran Syi'ah yang mengutuk Mu'awiyyah dan Yazid, yang telah merampas hak khalifah dari tangan Ali bin Abi Ṭalib dan membunuh anaknya, Husain di Karbala.68

Akan tetapi dari fatwa-fatwa yang dikeluarkan oleh al-Ranīī, nampaknya fatwa yang ditujukan untuk menghakimi para pengikut paham Wujūdiyyat adalah fatwa yang paling keras. Fatwa yang dikeluarkan oleh al-Ranīī tersebut ternyata mengundang reaksi yang luas, tidak saja dalam batas wilayah Aceh, tetapi juga meluas ke wilayah lain sampai ke Haramayn. Bahkan menurut keterangan sarjana Belanda P. Voorhoeve dalam satu tulisannya sebagaimana dikutip oleh Ahmad Daudy mengatakan bahwa Shaykh Ibrahim Hasan al-Kurani, maha guru kebanyakan ulama Indonesia mengecam keras fatwa tersebut dan mengingatkan melalui karya tanggapannya atas fatwa yang dikeluarkan oleh alRanīrī dan mengingatkan akan bahaya yang dapat ditimbulkan oleh penafsiran yang tidak memahami maksud ungkapan para sufi. ${ }^{69}$

Menurut keterangan, fatwa yang dikeluarkan oleh al-Ranīrī bukannya memperkokoh kedudukannya sebagai mufti, malah justru sebaliknya. Fatwa tersebut malahan menjadi bumerang baginya. Setelah ia melakukan eksekusi terhadap para pengikut paham Wujūdiyyat, ia harus meninggalkan Aceh dan

67Hasan, Warisan Intelektual Islam, 23.

${ }^{68}$ A. Hasyimi, Syi'ah dan Ahlussunah Saling Berebut Pengaruh dan Kekuasaan Sejak Awal Sejarah Islam di Kepulauan Nusantara (Surabaya: Bina Ilmu, 1983), 45-56.

${ }^{69}$ Daudy, Konsepsi Syeikh Nuruddin, 42-5; Shihab, Islam Sufistik, 52. 
kembali ke kampung halamannya, Ranir untuk selama-lamanya. Hal tersebut dijelaskan oleh salah satu muridnya dalam kolofon karya al-Raniri, Jawāhir al'Ulüm fi Kashfal-Ma'lūm:

"Maka kitab ini selesai dikarang pada hari senin, waktu dzuhur, 20 Zulhijjah 1076.... Kitab ini telah dikarang pengarangnya dari awal sampai akhir Bab Kelima. Setelah selesai bagian ini datanglah taqdir yang tak dapat ditolak. Ia berlayar (kembali ke tanah airnya Ranir pada tahun 1054 H, dan menyuruh salah seorang muridnya untuk menyelesaikannya".70

Informasi yang disampaikan muridnya di atas, ternyata tidak dapat memberikan informasi apa penyebab al-Ranīin pulang ke kampung halamannya. Adanya ketidakjelasan ini membuat para sarjana berspekulasi dalam mencari motifasi di balik kepulangan al-Ranīīi.

Ahmad Daudy dalam bukunya "Shaykh Nūr al-Dīn al-Ranīrì" berspekulasi bahwa pulangnya al-Ranīī ke tanah kelahirannya disebabkan oleh ketidaksukaannya terhadap kebijaksanaan Sultanah Safiyyat al-Dīn yang berencana menghukum mati orang-orang yang menolak diperintah oleh penguasa (raja) wanita. Mereka percaya, menurut tradisi setempat dan juga syari'at, tidaklah layak bagi wanita untuk jadi penguasa. Akibatnya timbul penentangan terhadap pemerintahannya; dan keberangkatan al-Ranīrī mewakili sikap oposisi tersebut.71 Spekulasi yang dilakukan oleh Ahmad Daudy ini, nampaknya mendapat bantahan dari Azyumardi Azra yang menurutnya alasan tersebut tidaklah masuk akal. Ia beralasan "Kita memang dapat mengharapkan munculnya semacam oposisi atau resistensi suatu masyarakat Muslim yang berorientasi pada syari'at terhadap pemerintahan seorang wanita. Namun, sepanjang menyangkut keberangkatan al-Ranīrī, sulit dipercaya, kembalinya ke kota kelahirannya disebabkan ketidaksukaannya diperintah oleh wanita yang telah menunjukan kebaikan hati kepadanya. Bahkan banyak karyanya yang ditulis untuk memenuhi perintah sang Sultanah, termasuk karya-karya yang ditulis pada saatsaat akhir sebelum keberangkatannya". ${ }^{72}$

Teka-teki keberangkatan al-Ranīrī secara mendadak itu pun akhirnya terjawab setelah Takeshi Ito menerbitkan sebuah artikel berjudul "Why did Nuruddin al-Raniri leave Aceh in 1054 H" yang ia dapatkan keterangannya dari

${ }^{70}$ Azra, Jaringan Ulama, 178.

${ }^{71}$ Ahmad Daudy, Syaikh Nūr al-Dīn al-Ranīri (Jakarta: Bulan Bintang, 1978), 17.

${ }^{72}$ Azra, Jaringan Ulama, 178. 
seorang opperkoopman (pedagang tinggi) Peter Sourji, yang pada tahun 1053 H/1643 M dikirim VOC sebagai komisaris perdagangan ke Jambi dan Aceh. Keterangan tersebut kemudian diyakini oleh para sarjana Indonesia sebagai data yang lebih akurat. Lihat saja misalnya Azyumardi Azra yang dengan yakin mengutip pendapat tersebut dalam bukunya, ${ }^{73}$ atau Ahmad Daudy yang kemudian merubah spekulasi dan mengganti penjelasannya dalam bukunya "Allah dan Manusia" mengatakan bahwa kepergian al-Raniri yang mendadak itu diakibatkan oleh kekalahan yang dialaminya dari serentetan diskusi keagamaan yang terjadi dengan Saif al-Rijāl, seorang ulama yang berpaham Wujūdiyyat yang baru kembali dari India. ${ }^{74}$ Menurut keterangannya, Ulama tersebut berasal dari Minangkabau dan pernah tinggal beberapa lama di Aceh untuk belajar pada Shaykh Maldin. ${ }^{75}$ Shaykh Maldin adalah seorang ulama berpaham Wujūdiyyat dari kalangan murid Shams al-Dīn al-Sumatrānī, dan kemudian ia melanjutkan studinya ke India. Menurut keterangan Shaykh Maldin adalah seorang mufti pada masa Sultan Iskandar Tsāni, akan tetapi karena suatu kesalahan, ia diusir dari Aceh dan akhirnya digantikan oleh al-Ranīī yang baru tiba dari Ranir.76 Bertemunya dua tokoh tersebut (al-Ranīrī dan Saif al-Rijāl) ternyata membuat perdebatan disekitar paham Wujūdiyyat menjadi kian menarik. Dan perdebatan tersebut pada akhirnya dimenangkan oleh Saif al-Rijāl. Kondisi tersebut membuat para ulama lainnya berbalik arah yang tadinya mendukung al-Ranīī menjadi mendukung Saif al-Rijāl, sehingga pada akhirnya al-Ranīrī terdesak dan memutuskan pulang ke negerinya India. Jabatan mufti pun kemudian beralih ketangan ulama berpaham Wujūdiyyat yakni Saif al-Rijāl. ${ }^{77}$

Polemik antara al-Ranīī dan Saif al-Rijāl tersebut sebenarnya telah diungkapkan oleh al-Ranīī dalam salah satu karyanya:

Kemudian dari itu maka datanglah Saif al-Rijāl, maka berbahaslah ia dengan kami seperti bahas mereka itu yang dahulu juga. Maka jawab kami: "Betapa kau benarkan akan kaum yang berkata: Wa Allah bi Allah ta Allah, insan itulah Allah dan Allah itulah insan?....maka sahutnya (Saif al-Rijāl): "Inilah iktikadku dan itikad segala ahli Makkah dan Madinah....." maka

${ }^{73}$ Azra, Jaringan Ulama, 178.

${ }^{74}$ Daudy, Konsepsi Syeikh Nuruddin, 45.

75Daudy, Konsepsi Syeikh Nuruddin, 46.

76Daudy, Konsepsi Syeikh Nuruddin, 46.

77Daudy, Konsepsi Syeikh Nuruddin, 46. 
berlanjutanlah perkataannya, maka kembalilah kebanyakan orang kepada iktikad yang sesat itu juga. ${ }^{78}$

Kekalahan dalam perdebatan bagi al-Ranīrī membuat ia harus angkat kaki dan meninggalkan Aceh pada tahun 1054 H/1644-45 M, sebagaimana disebutkan dalam catatan pada karyanya Jawāhir al-Ulūm fi Kasyf al-Ma'lūm. Dia melewatkan kehidupannya selama 14 tahun di Ranir sepulangnya dari Aceh. Meskipun ia tidak berada lagi di negeri Aceh, akan tetapi ia tetap masih peduli pada masyarakat Muslim di Nusantara. ${ }^{79} \mathrm{Al}$-Hasani sebagaimana dikutip oleh Azyumardi Azra meriwayatkan setelah kembali ke tanah kelahirannya, al-Ranīrī masih tetap menulis, sedikitnya tiga buah karya atau menurut Ahmad Daudy ${ }^{80}$ dan Alwi Shihab ${ }^{81}$ dua buah karya telah dihasilkannya, yang berkaitan dengan masalah-masalah yang dihadapi oleh masyarakat Aceh. Salah satu karyanya yang ia tulis sebagai jawaban atas pertanyaan yang diajukan oleh Sultan Banten, Abu al-Mufakir 'Abd al-Qadir al-'Ali. Al-Ranīrī menghembuskan nafas terakhirnya pada hari sabtu, 22 Zulhijjah 1068 H/ 21 September 1658.82

Meskipun al-Ranīī tinggal di Aceh tidaklah lama hanya sekitar tujuh tahun, akan tetapi namanya masih dikenang oleh masyarakat Aceh khususnya dan Nusantara umumnya. Hal tersebut bisa dilihat dengan diabadikan namanya menjadi nama salah satu perguruan tinggi Islam yang ada di Nusantara, yaitu IAIN Al-Raniri yang berlokasi di Provinsi Aceh. Hal tersebut menurut Alwi Shihab mengindikasikan bahwa pemikiran-pemikiran al-Ranīrī dapat mereduksi laju perkembangan tasawuf falsafi dan ajaran pantaisme di Aceh disatu pihak, dan melapangkan jalan bagi kemajuan tasawuf Sunni, di pihak lain. Pemikiran-pemikiran al-Ranīrī telah berhasil memantapkan pengaruh dan dominasi Ahl al-Sunnah wa al-Jamäăah.83

Al-Ranīrī adalah seorang tipe ulama yang sangat berani dan produktif, lihat saja begitu banyaknya karya yang telah dihasilkannya. Menurut Ahmad Daudy ${ }^{84}$

\footnotetext{
${ }^{78 N u ̄ r}$ al-Dīn al-Ranīrī, Fath al-Mubīn. Ungkapan ini pun dikutip oleh Hasymy, Syi'ah dan Ahlussunah, 107-109.

${ }^{79}$ Azra, Jaringan Ulama, 180.

80Daudy, Konsepsi Syeikh Nuruddin, 47.

81Shihab, Islam Sufistik, 52.

82Shihab, Islam Sufistik, 52.

${ }^{83}$ Shihab, Islam Sufistik, 48-49.

${ }^{84}$ Daudy, Konsepsi Syeikh Nuruddin, 48-57.
} 
dan Azyumardi Azra85 ada sekitar 29 buah buku karangannya, sedangkan menurut Alwi Shihab ada sekitar 30 judul buku telah dihasilkannya. ${ }^{86}$ Adapun dianatara karya-karya al-Ranīīi adalah sebagai berikut: Pertama, al-Shirāth alMustaqim, dalam bahasa Indonesia dengan topik pembahasan bidang fikih meliputi shalat, puasa, zakat, haji, dan kurban, serta hukum-hukumnya. Kedua, Durrah al-Farāildh fi Sharh al-'Aqāild, dalam bahasa Indonesia dengan topik pembahasan analisis kritik terhadap Sharh al-'Aqā'id al-Nasafiyyāh, karya Imam Sa'duddin al-Taftazani. Ketiga, Hidāyah al-Habīb fi al-Targhïb wa al-Tarhïb fi alHadith, dalam bahasa Arab dan Indonesia memuat 831 hadis. Keempat, Bustān alSaläțin fi Dhikr al-Awwalīn wa al-Äkhirin, merupakan karya terbesar dalam sejarah wilayah Aceh, dengan topik pembahasan meliputi sejarah nabi-nabi, rajaraja, menteri-menteri, dan wali-wali. Pada bagian penutup sejarah negeri-negeri Melayu, sedangkan bab terakhir membicarakan akal, firasat, sifat-sifat perempuan, dan cerita-cerita "aneh", dan masih banyak lagi karya-karya lainnya.

\section{Kritik Shaykh Nūr al-Dīn al-Ranīrī terhadap Wujūdiyyat}

Istilah wujūdiyyat sebenarnya istilah yang digunakan oleh al-Ranīrī sendiri dalam mengkritik pemikiran tasawuf Hamzah Fansūrī. Sebab dari seluruh karya yang ditulis oleh para ulama sebelum dan selain al-Ranīī istilah ini tidak pernah ditemukan, bahkan dalam karya Hamzah Fansūrī sendiri istilah ini tidak ditemukan. Menurut beberapa tokoh, istilah wujüdiyyat mempuyai persamaan arti dengan istilah waḥdat al-wujūd, suatu paham yang dicetuskan oleh Ibn 'Arabī, meskipun bukan dia yang menamakannya akan tetapi muridnya yakni alQunawi. Istilah wujūdiyyat yang dicetuskan oleh al-Ranīrī inilah sehingga para sarjana atau peneliti menggunakannya sampai saat ini.

Kritik al-Ranīrī terhadap mistik Hamzah Fansūrī ternyata menjadi perhatian yang menarik. Banyak hasil penelitian telah dilakukan dengan beragam hasil penemuan, ${ }^{87}$ di satu pihak membenarkan kritikan tersebut, di pihak lain mengkritik kritikan al-Ranīrī yang dianggapnya kurang tepat. Kajian tentang polemik tersebut, ternyata cukup ramai juga dikaji oleh ilmuan dalam negeri sebut saja misalnya Ahmad Daudy, ${ }^{88}$ Abdul Hadi W. M. ${ }^{89}$ Alwi Shihab, ${ }^{90}$ dan Afif Anshori. ${ }^{91}$

${ }^{85}$ Azra, Jaringan Ulama, 180.

86Shihab, Islam Sufistik, 51-52.

87Diantara hasil Penelitian: C.A.O. Van Nieuwen Huyse, Nur al-Din al-Raniri als Bestrijder der Wugudija, (BKI 104, 1952), al-Attas, The Mysticism of Hamzah Fansuri.

88Daudy, Konsepsi Syeikh Nuruddin. 
Adapun permasalahan yang mendapat kritikan dari al-Ranīrī sebagaimana diungkapkan oleh al-Attas dapat disimpulkan sebagai berikut: 1) Hamzah mengajarkan ajaran Wujūdiyyat dalam arti Tuhan berada dalam kandungan (immanen) alam ini. Ini artinya, Tuhan adalah hakikat fenomena alam empiris. 2) Hamzah mengatakan bahwa nyawa itu bukan Khalik dan bukan makhluk. 3) Hamzah mengatakan bahwa al-Qur'an itu makhluk. 4) Hamzah mengatakan bahwa nyawa berasal dari Tuhan dan akan kembali bersatu dengan-Nya, seperti ombak kembali ke laut.92

Dari empat permasalahan di atas, yang menjadi perhatian penting adalah permasalahan yang pertama yakni permasalahan tentang tanzīh (menyatakan bahwa Tuhan melebihi sifat atau kualitas apa pun yang dimiliki oleh makhlukmakhluknya) dan tasybīh (menyerupakan Tuhan dengan ciptaan-ciptaan-Nya) atau dalam istilah teologi transendensi (Tuhan berada jauh di luar alam) dan imanensi (yang ada dalam/berada dalam struktur) Tuhan.

Sebagai puncak dari permusuhannya itu, al-Ranīrī mengatakan bahwa perkataan-perkataan golongan Wujūdiyyat lebih jahat dibandingkan dengan perkataan Namrud dan Fir'aun. Untuk itu, pihak penguasa atau raja dan orangorang besar di seluruh negeri membakar karangan dua ulama zindik itu dan menghukum mati setiap pengikutnya (Hamzah Fansūrī dan Shams al-Din alSumatrānī), karena mereka telah menyekutukan Allah dengan berkata "alam dan manusia ialah wujudnya Allah."

\section{E. Tinjauan Atas Kritik Shaykh Nūr al-Dīn al-Ranīrī terhadap Konsep Wujūdiyyat Hamzah Fansūrī}

Hamzah Fansūrī adalah seorang ulama sekaligus juga penyair yang memercikkan "api" paham yang dianggap menyimpang yakni paham Wujüdiyyat. Percikkan "api" tersebut lambat laun menjadi kobaran "api" yang berujung diklaimnya menjadi seorang yang membawa paham kesesatan. Jika kita mengingat pertentangan antara al-Ranīrī dan Hamzah Fansūrī, maka kita akan ter-

\footnotetext{
${ }^{89}$ Muthari, Tasawufyang Tertindas.

${ }^{90}$ Shihab, Islam Sufistik.

${ }^{91}$ Anshori, Tasawuf Falsafi.

92al-Attas, The Mysticism, 31.
} 
ingat kondisi serupa yang menimpa Ibn 'Arabī dan para pengikutnya yang juga divonis serupa oleh Ibn Taimiyah.

Kondisi tersebut sangatlah wajar terjadi mengingat Hamzah Fansūrī adalah pengagum ajaran Ibn 'Arabī dan ulama-ulama sufi serupa lainnya. Hal tersebut terlihat dalam beberapa karyanya Asrār al-'Ārifin, Sharh al 'Āshiqīn, al-Muntahī, ia banyak mengutip ucapan-ucapan para tokoh sufi seperti Abu Yazid al-Bisthami yang mengajarkan paham ittih $\underline{a} d{ }^{93}$ al-Hallāj yang mengajarkan paham $\underline{h} u l \bar{u} l,{ }^{94}$ Ibn 'Arabī yang mengajarkan waḥdat al-wujūd. Sementara itu di dalam karyakarya lainnya yang berbentuk syair, ia banyak mengutip pendapat beberapa ulama sufi lainnya seperti Fariduddin al-Attar, Syekh Junaid al-Baghdadi al-Iraqi dalam karyanya Manțiq al-Ṭayr, Lama'at, Jami', dan ulama sufi lainnya. Akan tetapi dalam syair-syairnya, Hamzah Fansūrī nampak lebih banyak mengutip ucapan-ucapan al-Iraqi dalam kitabnya Lama'at, hal tersebut menurut Abdul Hadi memeperlihatkan adanya pertalian istimewa antara pandangan Hamzah Fansūrī dengan Fakhruddin al-Iraqi. ${ }^{95}$

Berbeda dengan penjelasan di atas, ternyata banyak orang beranggapan bahwa ajaran Wujūdiyyat yang dibawa oleh Hamzah Fansūrī yang kemudian berkembang di Indonesia sampai saat ini adalah merupakan ajaran yang menginduk atau hasil tafsiran dari ajaran martabat tujuh. Pendapat tersebut jika ditelusuri adalah tidak benar. ${ }^{96}$ Sebab jika kita melihat sejarah, ajaran martabat tujuh baru berkembang pada awal abad ke-17 dengan Shaykh Syamduddin Pasay sebagai penganjur pertama. ${ }^{97}$

Menurut Abdul Hadi, Syekh Hamzah Fansūrī dan juga para wali di pulau Jawa abad ke-16 seperti Sunan Bonang dan Sunan Kalijaga, tidak pernah men-

\footnotetext{
${ }^{93}$ Ajaran ini mengajarkan bahwa manusia dapat bersatu dengan Tuhan, setelah melewati fase fana (pengosongan diri) dan kemudian baqa' (hidup dalam diri Tuhan). Abū al-Wafā' al-Ghunaimī alTaftazānī, Madkhal ilā al-Tașawwuf al-Islāmī (Kairo: Dār al-Thaqāfah, 1983), 113-15.

${ }^{94}$ Ajaran ini menyatakan bahwa Tuhan memilih tubuh manusia pilihan untuk mengambil tempat dalam dirinya, setelah sifat-sifat buruk dalam tubuh itu dihilangkan. Abū Nāṣir al-Ṭusi, alLuma'(Kairo: Dār al-Kutub al-Hadīthāt, 1960), 299.

${ }^{95}$ Muthari, Hamzah Fansuri, 21; senada dengan Braginsky, Tasawuf dan Sastra Melayu (Jakarta: RUL, 1993), 38-45.

96Muthari, Hamzah Fansuri, 20: Atau lihat juga pendapat yang menolak anggapan tersebut, seperti Simuh. Simuh, Mistik Islam Kejawen Raden Ngabehi Ranggawarsito (Jakarta: UI Press, 1988), 330-334.

${ }^{97}$ Muthari, Hamzah Fansuri, 20.
} 
jadi penganjur ajaran martabat tujuh.98 Meskipun begitu memang ajaran martabat tujuh termasuk ajaran Wujūdiyyat, namun telah menempuh perkembangan agak lain dan kedalamnya telah terasuki pengaruh India, seperti praktik Yoga di dalam amalan dzikirnya, dan hal itu merupakan hal yang dikritik oleh Hamzah Fansūrī dalam karyanya. Penggagas ajaran martabat tujuh adalah Mohammad Fadhullāh al-Burhanpuri (w. 1620), adalah merupakan ulama yang berasal dari India dan ketika ajaran ini diasaskan, berbagai gerakan sinkritis keagamaan dan mistik telah berkembang di India, khususnya pada masa Sultan Akbar dan Dara Sukoh. Dari data ini semakin jelaslah bahwa Hamzah Fansūrī tidak memiliki hubungan dengan tasawuf yang berkembang di India pada abad ke-16 dan ke-17.99

Al-Ranīrī menganggap Hamzah Fansūrī melalui karya-karyanya berpaham bahwa Tuhan itu imanen dengan segala ciptaan-ciptaan-Nya. Sehingga dengan demikian Hamzah Fansūrī dapat digolongkan menganut paham panteisme. Jika kita perhatikan ungkapan dan syair berikut ini, maka kesan demikian akan terasa benar:

"Segala rupa-rupa-Nya; segala warna, warna-Nya;

segala bunyi, bunyi-Nya; karena Ia Wahdahū lā syarīka lahū.

Jikalau dikatakan ada yang lain daripada-Nya,

syirik dengan zhulm hukumnya".

Juga diungkapkan dalam syairnya:

"Hakikat itu terlalu 'iyan

Pada rupa kita sekalian insan

Ayna mã tuwallū suatu burhān

Fa tsamma wajhu Allāh pada sekalian maqām"

Dari ungkapan tersebut maka al-Raniri menganggap Hamzah Fansūrī berprilaku syirik dengan mempersamakan Tuhan dengan makhluk, seolah-olah tiada perbedaan, dan mempertuhankan api, air, tanah dan udara dalam karyanya. Anggapan al-Ranīīi di atas akan terbantahkan jika kita melihat keterangan Hamzah Fansūrī yang ada dalam kitab Asrār al-'̄rrifin:

"Fa'lam-hukum dua lagi: khadim dan ratu, Ya'ni jangan menyembah cahaya seperti embun dan matahari dan bulan dan bintang, dan seperti

98Muthari, Hamzah Fansuri, 20.

${ }^{99}$ al-Attas, The Mysticism, 16-7. 
rupa budak; dan jangan ber-maqam di ubun-ubun, atau di antara kening atau di pucuk hidung, atau di dalam jantung. Sekalian ini hijab kepada DzatNya. Adapun akan orang Ahli Suluk, da'im (ia) menyerahkan diri (nya) kepada Tuhannya".100

Keterangan lain yang diungkapkan Hamzah Fansūrī

"Sungguh pun dzat dapat diibaratkan, tetapi tiada lulus pada ibarat karena tiada di atas akan Dia, tiada di bawah akan Dia, tiada dahulu akan Dia, tiada kemudian akan Dia, tiada kanan akan Dia, tiada kiri akan Dia, tiada jauh akan Dia, tiada hampir akan Dia, tiada di luar akan Dia, tiada di dalam akan Dia, tiada bercerai akan Dia, tiada bertemu akan Dia, tiada dengan betapanya, dan tiada di mana dan tiada ke mana, dan tiada sekarang dan tiada sekedjap mata, dan tiada ketika dan tiada masa; tiada Ia jadi dan tiada Ia menjadi, tiada Ia tempat dan tiada Ia bertempat....

Firman Allah ta'ala: "Subhāna l-Lah'ammā yashifūn". Yakni Maha Suci Allah tiada dapat di perikan. Lagi Firman Allah ta'ala: "laisa kamisylihì syai'un". Yakni Tiada suatu pun barang yang kita bicarakan dengan hati kita atau dengan makrifat kita sudah-sudah, yaitu sama-sama".101

Tudahan selanjutnya yang di tujukan pada Hamzah Fansūrī bahwa ia penganut paham ḥulūl (inkarnasi) yang dinisbatkan pada al-Hallāj dan ittih $\underline{a} d$ yang dinisbatkan pada Suhrawardi al-Maqtūl.102 Pendapat tersebut bertentangan dengan ucapan syair Hamzah Fansūrī:

"Aho segala kita umat Rasul

Tuntut ilmu haqīqāt al-wușūl

I'tiqād-mu jangan ittihāàd dan ḥulūl".

Tuduhan yang lain yang ditujukan al-Ranīrī pada Hamzah Fansūrī adalah Hamzah Fansūrī dianggap tidak mementingkan syari'at untuk ditegakkan. Padahal kalau kita melihat ucapan Hamzah dan syairnya, maka anggapan itu akan terbantahkan.

Aho segala kita anak Adam

Jangan lupa akan Syahi 'Alam

Pada bahr al-dzunūb jangan terkaram

Supaya 'asyīq siang dan malam

100al-Attas, The Mysticism of Hamzah Fansuri, 287.

101Daudy, Allah dan Manusia, 214.

102Daudy, Allah dan Manusia, 228. 
'Asyīq-mu itu jangan bercawang

Meninggalkan dunya jangan kepalang

Suluh Muhammad yogya kau pasang

Pada Rabb al-ālamin supaya kau datang

Syari'at Muhammad terlalu 'amīq

Cahayanya terang di Bayt al-'Athïq

Tandanya ghalib lagi sempurna tharī

Banyaknya kafir menjadi raīq

Bayt al-'athïq itulah nama ka'bah

Ibadat di dalamnya tiada berlelah

Tempatnya ma'lūm di tanah Makkah

Akan kiblat Islam menyembah Allah

Berkaitan dengan ungkapan-ungkapan shațahat dan tuduhan meninggalkan syari'at. Al-Ranīrī telah menilai Hamzah Fansūrī membolehkan penganjuran ucapan-ucapan tersebut, dan hal ini menurut al-Ranīrī adalah prilaku yang menyimpang. Jika kita menelusuri ungkapan-ungkapan Hamzah Fansūrī maka anggapan tersebut jelas akan terbantahkan:

"Banyak lagi mashāikh yang berkata demikian (ungkapan-ungkapan shathahat) tiada tersebut. Adapun mereka itu sekalian berkata demikian karena makrifat mereka itu sempurna. Jangan kita yang tiada bermakrifat berkata demikian, jangan kita turut-turutan, maka dikufurkan pandita yang menghukumkan demikian supaya jangan segala yang jahil, yang tiada bermakrifat mengatakan demikian, karena makrifat itu terlalu musykil. Barangsiapa belum sempurna bermakrifat dan berahi seperti mereka itu, jika ia berkata seperti mereka itu, kafir hukumnya". ${ }^{103}$

Lebih lanjut berkaitan dengan amalan syari'at Hamzah Fansūrī menambahkan:

"Jangan kita meninggalkan sembahyang dan jangan kita meninggalkan syari'at karena syari'at dengan hakikat esa jua. Barangsiapa belum mabuk atau mahwu (hilang sadar) atau belum junun (gila) datang daripada Allah, jikalau meninggalkan sembahyang dan puasa dan makan haram fisik dan 'ạsi (durhaka) mereka itu hukumnya". ${ }^{104}$

103Daudy, Allah dan Manusia, 217.

${ }^{104}$ Daudy, Allah dan Manusia, 214. 
Dari penjelasan-penjelasan di atas, jelaslah tuduhan-tuduhan yang dilayangkan al-Ranīrī terhadap Hamzah Fansūrī tidaklah terbukti. Lantas pertanyaan yang muncul kemudian adalah apa motivasi al-Ranīrī mengkritik Hamzah Fansūrī? Apakah ada perbedaan sudut pandang antara Hamzah Fansūrī dan al-Ranīrī dalam melihat konsep Wujūdiyyat?

Jika melihat dari mana al-Ranīrī berasal, maka bisa ditarik titik temu salah satu penyebab pertentangan tersebut. Al-Ranīrī adalah seorang ulama yang berasal dari India. Pada masa al-Ranīrī tinggal di India, kondisi India pada waktu itu diselimuti oleh permusuhan antara penganut Hindu dan penganut Islam yang minoritas. Sehingga dengan begitu konflik sosial dan keagamaan yang berkepanjangan antara muslim dan Hindu membuatnya tidak bisa toleran di dalam segmen-segmen kedua golongan masyarakat itu.

Jika melihat dari akar substansi konflik tersebut, maka akan ditemukan sudut pandang yang berbeda antara keduanya. Al-Ranīrī dalam melihat konsep Wujūdiyyat mensintesakan dua kutub yang berbeda; yakni antara kutub mutakallim dan kutub sufi. Permasalahan tentang perdebatan wujud Allah sebenarnya antara al-Ranīrī dan aliran-aliran kalam baik Asy'ariyah maupun Mu'tazilah terdapat perbedaan yang mendasar. Hal tersebut terwujud dari pendapatnya yang memandang tidak perlu membuktikan wujūd (keberadaan Allah), mengingat hal itu merupakan kepastian yang telah final dalam persepsi akal maupun wahyu. Ia berpendirian bahwa adanya Allah merupakan suatu kenyataan iman yang harus diyakini. Sebagaimana ungkapannya:

"Menurut para ahli kalam, wujud dua macam: wujud hakiki dan wujud alam; keberadaan Allah merupakan wujud pasti, sedangkan keberadaan alam wujud mumkin (ketergantungan), yang berarti Allah yang mengadakan alam sehingga menjadi wujud empiris. Artinya, keberadaan alam tergantung kepada Allah oleh karena itu, hakikat kedua wujud tersebut berbeda, yang pertama qadim (keberadaan awal yang tidak didahului wujud apa pun); dan yang kedua 'tercipta" dan "baru". Dari sini, menurut ahli kalam, wujud dua macam: yang pertama, wujud Allah sedangkan wujud yang kedua bersifat majazi, yakni milik wujud Allah (yang dipinjamkan). Apabila keduanya tidak berbeda berarti menjadi satu. Oleh karena itu, setiap yang percaya bahwa Allah dan alam merupakan satu wujud, berarti dia telah kafir mengingat wujud Allah dan wujud alam bukan satu wujud".105

\footnotetext{
${ }^{105}$ Nūr al-Dīn al-Ranīrī, Hujjah al-Șiddīq li Dafi al-Zindīq, dikutip dari Syed Muhammad Naquib al-Attas, "Raniri and the Wujudiyyah of 17th Century Acheh" (Montreal, 1962), 82.
} 
Dalam masalah ketuhanan, nampaknya al-Ranīrī mengkompromikan antara pendapat mutakallim dan para sufi yang terwakili oleh Ibn 'Arabī. Dan antara keduanya saling berbeda. Para mutakallim nampak kecenderungannya untuk mempertahankan kesucian Allah dari sesuatu persamaan dengan makhluk-Nya (tanzih), sedangkan para sufi lebih memperlihatkan persamaan dalam kesatuan hakikat Allah dengan alam ini. Berdasarkan dua kutub yang berbeda itu, maka al-Ranīrī berusaha mengkompromikan dalam konsepsi lain. Sikap ini menurut Ahmad Daudy bukanlah sesuatu yang dibuat-buat, akan tetapi telah menjadi watak pembawaan dan keyakinannya sebagai seorang ulama $A h l$ al-Sunnah wa '-Jamā'ah dan seorang Shaykh dari tarekat Rifā'iyyah. ${ }^{106}$

Dalam menyikapi dua kutub yang berbeda pandangan itu, Al-Ranīī meskipun mengakui kebenaran dua pandangan di atas, akan tetapi nampaknya pandangan dari kutub ahli sufi mendominasi pandangannya. Hal tersebut dapat dilihat dari pendapatnya:

"Bahwa kami pun kabulkan akan iktikad dan perkataan Mutakallimin itu. Adapun istilah kami bahwa wujud itu esa jua, yaitu zat Allah ta'ala. Dan dalam itu tiada berwujud, dan tiada layak dinamai akan dia dengan nama wujud karena ia adam al-maḥ (tiada mutlak). Maka apabila adalah alam itu adam al-maḥd dan wujud Haqq Ta'ala itu wujūd al-maḥ̣ (wujud mutlak), maka manakah jadi sewujud 'adam al-maḥ dengan wujūd almahḍ?... maka wujūd Haqq Ta'ala dengan alam berlainan pun tiada dan bersuatu pun tiada, karena berlainannya dan bersuatu itu menghendaki dua wujūd muthqil (wujūd tersendiri) sendirinya. Maka apabila adalah wujūd Allah jua yang esa, dan alam itu tiada berwujud, maka tiadalah jadi berlain-lainan. Daripada karena inilah kami kata wujūd Allah dengan alam esa. Jikalau ada alam itu maujud kelihatan sekali pun tetapi tiada kebilangan wujudnya dari karena ia tiada berwujud hakiki". 107

Dari pernyataan di atas, nampaknya al-Ranīī di satu sisi sependapat dengan para mutakallim dan di sisi lain ia lebih sependapat dengan konsep waḥdatal-Wujūd Ibn 'Arabī dengan alasan:

"Adapun pendapat ahli sufi itu pun dengan dalili akal dan naql (wahyu) jua, lagi ditambah pula kashf dan dhawq (pengalaman batin). Maka ditilik mereka itu dengan mata hatinya dan dirasanya dengan perasaannya

\footnotetext{
106Daudy, Allah dan Manusia, 81-82.

${ }^{107}$ Daudy, Allah dan Manusia, 85.
} 
bahwa wujūd itu esa jua, yaitu wujūd Allah yang tiada kelihatan dengan mata kepala itu yaitu alam yang tiada berwujud seperti wujūd Allah. Maka wujūd Allah itu wujud hakiki lagi mutlak, dan wujud alam itu wujud majazi lagi muqayyad (relatif)—zill_dan milik bagi wujūd Allah. Maka akan zill (bayangan) itu tiada dapat dikata akan dia wujūd, dan tiada dapat dikata akan dia 'adam muțlāq; dari karena jika dikata akan dia wujūd niscaya sekutulah ia dengan wujūd Allah; dan jika dikata akan dia 'adam muțāq, maka 'adam itu tiada ada sesuatu syaj' jua pun, dan alam itu ada kelihatan. Maka nyatalah alam itu mazhar wujūd Haqq ta'ālā. Maka nisbah antara wujūd Allah dan alam itu bersuatu pun tiada dan berlainan pun tiada karena alam itu maẓhar dan milik bagi Allah ta'ala".108

Jika melihat berbagai pernyataan al-Ranīrī yang diungkapkan di atas, jelaslah bahwa ia tidak menolak ajaran Waḥdat al-Wujūd yang diajarkan oleh Ibn 'Arabī bahkan mengaguminya sebagai gagasan yang brilian. Akan tetapi kenapa al-Ranīrī justru bersikap sebaliknya menolak bahkan menuduh sesat ajaran yang dibawa oleh Hamzah Fansūrī yang merupakan seorang ulama pentafsir ajaran Waḥdat al-Wujūd Ibn 'Arabī di wilayah Aceh. Keanehan ini membuat spekulasi Syed Muhammad Naquib al-Attas yang mengatakan adanya muatan atau tendensi-tendensi kepentingan pribadi dan unsur politik (perebutan pengaruh rezim yang berkuasa) dalam pertentangan al-Ranīrī dan Hamzah Fansūrī mendapat ruang kebenarannya.

\section{F. Kesimpulan}

Sebagai kesimpulan akhir, dapat diungkapkan bahwa berdasarkan data di atas, pernyataan tuduhan bahwa Hamzah Fansūrī menyamakan Tuhan dengan alam sehingga tidak ada lagi perbedaan antar keduanya dan dengan demikian mengajarkan doktrin sesat, yang menyalahi ajaran tawhìd yang murni, tidak dapat dibenarkan. Kemudian apa yang disimpulkan oleh Ahmad Daudy bahwa Hamzah Fansūrī menganut paham panteisme tidaklah benar. Anggapananggapan di atas muncul akibat mereka melihat dan menonjolkan hanya pada sisi tashbịh dan immanensi Tuhan dalam doktrin Wujüdiyyat dan mengabaikan sisi tanzīh dan transendensi Tuhan. Justru Hamzah Fansūrī sangat menekankan kedua sisi ini dan memadukan antara keduanya. Karena alasan di atas, secara tegas dinyatakan bahwa tuduhan sesat atau menyesatkan yang dilontarkan oleh al-Ranīrì terhadap Hamzah Fansūrī tidak terbukti adanya.[]

108Daudy, Allah dan Manusia, 86. 


\section{DAFTAR PUSTAKA}

Agmasari, Silvita. "Temuan Ahli Antropologi di Balik Mantra Misterius dari Barus." National Geographic Indonesia, 2017. http://nationalgeographic. grid.id/read/13309094/temuan-ahli-antropologi-di-balik-mantramisterius-dari-barus.

Ahmad, Zakaria. Sekitar Kerajaan Atjeh dalam Tahun 1520-1675. Medan: Monora, 1972.

al-Attas, Syed Muhammad Naquib. "Raniri and the Wujudiyyah of 17th Century Acheh." Thesis, McGill University, Montreal, 1962.

——. Tasawwufal-Fansuri. Kuala Lumpur: University of Malaya Press, 1970.

-_- The Mysticism of Hamzah Fansuri. Kuala Lumpur: University of Malaya Press, 1970.

Anshori, M. Afif. Tasawuf Falsafi, Syaikh Hamzah Fansuri. Yogyakarta: Gelombang Pasang, 2004.

Arif, Abdulllah. "Syaikh Nūr al-Dīn al-Ranīrī Ulama/Politikus Abad XVII." dalam Tokoh-tokoh Sastra Melayu Klasik, terj. Muhammad Daud Mohammad. Kuala Lumpur: Dewan bahasa dan Pustaka Kementrian Pendidikan Malaysia, 1987.

Azra, Azyumardi. Jaringan Ulama Timur Tengah dan Kepulauan Nusantara Abad XVII dan XVIII. 4th ed. Bandung: Mizan, 1998.

Barwise, J. M., and N. J. White. A Traveller's History of Southeast Asia. New York: Interlink Books, 2002.

Braginsky. Tasawuf dan Sastra Melayu. Jakarta: RUL, 1993.

Daudy, Ahmad. Allah dan Manusia dalam Konsepsi Syeikh Nuruddin Ar-Raniry. Jakarta: Rajawali Press, 1983.

——C.Syaikh Nūr al-Dīn al-Ranīri. Jakarta: Bulan Bintang, 1978.

Djajadiningrat, R. Housen. Kesultanan Aceh: Suatu Pembahasan tentang Sejarah Kesultanan Aceh Berdasarkan Bahan-bahan yang Terdapat dalam Karya 
Melayu. ed. Teuku Hamid. Banda Aceh: Depdikbud \& Proyek Pengembangan Permesiuman Daerah Iistimewa Aceh, 1982.

Doorenbos, J. De Geschriften van Hamzah Pansoeri. Leiden: N.V. v.h. Batlejee dan Tremptra, 1933.

Guillot, Claude. Lobu Tua: Sejarah Awal Barus. Edited by Daniel Perret. Jakarta: Yayasan Pustaka Obor Indonesia, 2002.

Hasan, Ahmad Rifa'i. Warisan Intelektual Islam Indonesia; Telaah atas Karya-karya Klasik Bandung: Mizan, 1987.

Hasymy, A. Sejarah Masuk dan Berkembangnya Islam di Indonesia. Bandung: AlMa'arif, 1993.

-_- Syi'ah dan Ahlussunah Saling Berebut Pengaruh dan Kekuasaan Sejak Awal Sejarah Islam di Kepulauan Nusantara. Surabaya: Bina Ilmu, 1983.

Lombard, Denys. Kerajaan Aceh: Zaman Sultan Iskandar Muda (1607-1636). Jakarta: Kepustakan Populer Gramedia, 2006.

Muthari, Abdul Hadi Wiji. Hamzah Fansuri: Risalah Tasawuf dan Puisi-puisinya. Bandung: Mizan, 1995.

- - T Tasawuf yang Tertindas: Kajian Hermeneutik terhadap Karya-karya Hamzah Fansuri Jakarta: Paramadina, 2001.

al-Raniri, Nuruddin. Bustān al-Salāțīn fi Dhikr al-Awwalīn wa 'l-Ākhirīn. ed. T. Iskandar. Kuala Lumpur: Dewan Bahasa dan Pustaka, 1966.

Ricklefs, M. C. A History of Modern Indonesia Since c. 1300. 2nd ed. Stanford: Stanford University Press, 1994.

Said, Muhammad. Aceh Sepanjang Abad. Medan: PT. Percetakan dan Penerbitan Pustaka, 1981.

Shihab, Alwi. Islam Sufistik: Islam Pertama dan Pengaruhnya hingga Kini di Indonesia. Bandung: Mizan, 2001.

Simanungkalit, Edward. "Barus: Kota Prasejarah Nusantara." Majalah Kirana. Surabaya, 2008.

Simuh. Mistik Islam Kejawen Raden Ngabehi Ranggawarsito. Jakarta: UI Press, 1988. 
al-Taftazānī, Abū al-Wafā' al-Ghunaimī. Madkhal Ilā 'l-Tașawwuf al-Islāmī. Kairo: Dār al-Thaqāfah, 1983.

Tim Penyusun Kamus. Pusat Pembinaan dan Pengembangan Bahasa. Kamus Besar Bahasa Indonesia. Jakarta: Depdikbud \& Balai Pustaka, 1980.

al-Ṭusi, Abū Nāṣir. Al-Luma'. Kairo: Dār al-Kutub al-Ḥadīthāt, 1960. 
